\title{
Hepatocyte growth factor in patients with three different stages of chronic liver disease including hepatocellular carcinoma, cirrhosis and chronic hepatitis: An immunohistochemical study
}

Banu Bilezikçi MD, Asuman Nihan Haberal MD, Beyhan Demirhan MD

B Bilezikçi, AN Haberal, B Demirhan. Hepatocyte growth factor in patients with three different stages of chronic liver disease including hepatocellular carcinoma, cirrhosis and chronic hepatitis: An immunohistochemical study. Can J Gastroenterol 2001;15(3):159-165.

BACKGROUND AND AIMS: The specific role of hepatocyte growth factor in liver disease is unknown. The presence and density of this factor in patients with three different stages of liver disease were investigated, with the aim of assessing its prognostic significance.

PATIENTS AND METHODS: Liver specimens from patients with chronic hepatitis $(n=20)$, cirrhosis $(n=20)$, hepatocellular carcinoma $(n=30)$ and normal livers $(n=20)$ were immunohistochemically stained to determine the presence and density of hepatocyte growth factor.

RESULTS: There were significantly more hepatocyte growth factor-positive Kupffer and Ito cells in all three diseased groups than in the control group. Also, there was significantly more positive staining in chronic hepatitis specimens than in specimens from the cirrhosis, hepatocellular carcinoma and control groups $(\mathrm{P}<0.05)$. The hepatoma cells in 10 of the hepatocellular carcinoma cases stained positive, but none of the hepatocytes in the chronic hepatitis, cirrhosis and normal liver specimens stained. It was only possible to assess nonmalignant hepatocytes adjacent to the hepatocellular carcinoma in the four resection specimens, and no staining for hepatocyte growth factor was observed in these areas. There was no statistical association between density of hepatocyte growth factor and histological activity index in chronic hepatitis, or between density of hepatocyte growth factor and grade of hepatocellular carcinoma. CONCLUSIONS: Similar to some previous reports, this study revealed that hepatoma cells can also express this growth factor. Immunohistochemical detection of hepatocyte growth factor may prove to be a useful method of diagnosing hepatocellular carcinoma in challenging cases.

Key Words: Chronic hepatitis; Cirrhosis; Hepatocellular carcinoma; Hepatocyte growth factor

Pour le résumé, voir page suivante

Baskent University Faculty of Medicine, Department of Pathology, Bahçelievler, Ankara, Turkey

Correspondence and reprints: Dr Banu Bilezikçi, Baskent Üniversitesi Tip Fakültesi Patoloji Anabilim Dali 12, Sokak No 7/1 Bahçelievler,

Ankara, Turkey. Telephone +90-312-212-65-91, fax +90-312-212-75-72, e-mail banubil@yahoo.com

Received for publication July 27, 2000. Accepted December 19, 2000 


\section{Facteur de croissance des hépatocytes chez des patients souffrant de maladies du foie de trois stades différents, comprenant un carcinome hépatocellulaire, une cirrhose et une hépatite chronique : une étude immunohistochimique}

CONTEXTE ET BUTS : Le rôle spécifique du facteur de croissance des hépatocytes dans les maladies du foie demeure inconnu. La présence et la densité de ce facteur ont été étudiées chez des patients atteints de maladies du foie de trois stades différents, en vue d'évaluer sa signification pronostique.

PATIENTS ET MÉTHODES : Des échantillons du foie de patients souffrant d'hépatite chronique $(n=20)$, de cirrhose $(n=20)$ et de carcinome hépatocellulaire $(\mathrm{n}=20)$ ainsi que de patients ayant un foie normal $(n=20)$ ont été colorés par immunohistochimie afin de déterminer la présence et la densité du facteur de croissance des hépatocytes.

RÉSULTATS : On a observé une quantité sensiblement plus importante dans les groupes de patients malades que dans le groupe témoin de résul- tats positifs pour le facteur de croissance des hépatocytes dans des cellules de Kupffer et de Ito. En outre, la coloration positive était significativement plus importante dans les échantillons d'hépatite que dans les échantillons de cirrhose, de carcinome hépatocellulaire et du groupe témoin $(\mathrm{p}<0,05)$. La coloration des cellules de carcinome hépatocellulaire a été positive dans 10 cas sur 20, mais aucun hépatocyte dans les échantillons d'hépatite chronique, de cirrhose et de foie normal n'a été coloré. Il a été possible uniquement d'évaluer les hépatocytes non malins adjacents au carcinome hépatocellulaire dans les quatre échantillons de résection, et aucune coloration pour le facteur de croissance des hépatocytes n'a été observée dans ces régions. Aucune association statistique ne fut établie entre la densité du facteur de croissance des hépatocytes et l'indice d'activité histologique dans l'hépatite chronique ou entre cette même densité et le grade du carcinome hépatocellulaire.

CONCLUSIONS : Cette étude, comme d'autres rapports antérieurs, a révélé que les cellules d'hépatome peuvent également exprimer ce facteur de croissance. La détection par immunohistochimie du facteur de croissance des hépatocytes pourrait s'avérer une méthode utile pour le diagnostic du carcinome hépatocellulaire dans les cas difficiles.
$\mathrm{H}$ epatocyte growth factor (HGF), originally described as a hepatocyte-specific mitogen, has been shown to be a potent stimulator of DNA synthesis in a variety of cell types (1-5). This growth factor also acts as a motogen, morphogen and tumour inhibitor (6). HGF-producing cells in the liver are nonparenchymal, presumably Kupffer, Ito and sinusoidal endothelial cells (7-9). This factor is also present in many organs other than the liver, and HGF messenger RNA expression is enhanced in the lung, kidney and spleen after liver damage. These findings have led to the characterization of HGF as an endocrine or paracrine factor that acts on hepatocytes and other organs (10). Levels of HGF may vary due to enhanced production or decreased hepatic clearance, or through both of these routes (10). The HGF receptor is a tyrosine kinase type encoded by the c-met proto-oncogene. The relationship between c-met and HGF expression may play an important role in hepatocellular carcinogenesis, metastasis and prognosis (11-13).

The aim of the present study was to determine the density of HGF-positive cells in three different stages of liver disease using immunohistochemical technique. Also examined were the relationship between histological activity index (HAI) and HGF staining density in chronic hepatitis (CH) specimens, and the link between HGF staining density and histological grade in hepatocellular carcinoma (HCC) specimens.

\section{PATIENTS AND METHODS}

Patients: Seventy patients with liver disease, 20 with $\mathrm{CH}$ (group I), 20 with cirrhosis (group II) and 30 with HCC (group III) were determined. Twenty normal liver biopsies were obtained as controls. Serological markers, abdominal ultrasonography, computed tomography and determination of alpha-fetoprotein levels were used to diagnose the three types of liver diseases, and all diagnoses were confirmed histologically. The clinical findings of patients with HCC are summarized in Table 1 . The causes of the patients' liver dis- ease are presented in Table 2. At the time of biopsy, patients with HCC and patients with cirrhosis were not undergoing any specific therapy. In the $\mathrm{CH}$ group, one patient had been receiving steroid treatment for eight months, and three had been receiving interferon therapy for seven months at the time of biopsy. All but four specimens (resection samples in HCC cases) were obtained by needle biopsy. Each case of $\mathrm{HCC}$ was graded according to the Edmondson and Steiner scheme (14). The histological activity of $\mathrm{CH}$ was determined according to the method of Knodell et al (15).

Histochemistry: All specimens were fixed in 10\% formalin and were embedded in paraffin blocks. The blocks were then cut in serial sections of 4 to $5 \mu \mathrm{m}$ thickness, and deparaffinized sections were prepared with hematoxylin and eosin ( $H \& E)$, Masson trichrome, Manuel's reticulum stain and Perls' iron stain (16).

Immunohistochemistry: All samples were immunohistochemically analyzed using the avidin-biotin complex method. First, deparaffinized sections were incubated with primary antibodies (HGF/Scatter Factor Ab-2, Clone SBF5, monoclonal [NeoMarkers, USA]) in a 1:10 dilution at room temperature for $16 \mathrm{~h}$. The antibody used was a mouse monoclonal antibody of immunoglobulin G1 isotype that was raised against a recombinant human HGF protein. It is absolutely specific for HGF, and thus does not crossreact with other members of the Skingle-serine protease group, such as HGF1/macrophage-stimulating protein, plasminogen/plasmin, tissue plasminogen activator and urinary plasminogen activator. After the incubation period, the resultant reaction was visualized using the chromogen 3,3diamino-benzidine-tetrahydrochloride. The number of nonparenchymal cells (Kupffer, Ito and endothelial cells) per $\mathrm{mm}^{2}$ was determined by using an ocular micrometer; the mean positive cell count for each group of specimens was then calculated (CH, cirrhosis and HCC). One slide per patient was scored, and a mean of 1,074,000 cells/ $\mathrm{mm}^{2}$ were counted in each case. 
TABLE 1

Clinical findings in patients with hepatocellular carcinoma

\begin{tabular}{|c|c|c|c|c|c|c|c|c|c|c|}
\hline Patient & $\begin{array}{c}\text { Age } \\
\text { (years) }\end{array}$ & Sex & $\begin{array}{c}\text { Tumour } \\
\text { diameter }(\mathbf{m m})\end{array}$ & Anti-HCV & HBsAg & $\operatorname{AFP}(\mathrm{ng} / \mathrm{mL})$ & AST (U/L) & $\operatorname{ALT}(\mathrm{U} / \mathrm{L})$ & GGT (U/L) & $\mathrm{AP}(\mathrm{U} / \mathrm{L})$ \\
\hline 1 & 70 & M & 15 & $\varnothing$ & $\varnothing$ & $\varnothing$ & 108 & 60 & 369 & 324 \\
\hline 2 & 58 & M & 12 & $\varnothing$ & + & $\varnothing$ & $\varnothing$ & $\varnothing$ & $\varnothing$ & $\varnothing$ \\
\hline 3 & 51 & M & 90 & $\varnothing$ & $\varnothing$ & 76 & 45 & 28 & 270 & 75 \\
\hline 4 & 61 & M & 90 & $\varnothing$ & + & 4500 & 28 & 29 & 63 & 393 \\
\hline 5 & 49 & M & 80 & $\varnothing$ & + & 8.01 & 59 & 40 & 65 & 203 \\
\hline 6 & 55 & M & 25 & $\varnothing$ & + & 4.06 & 61 & 87 & 117 & 170 \\
\hline 7 & 64 & M & 100 & + & $\varnothing$ & 28.21 & 910 & 120 & $\varnothing$ & 100 \\
\hline 8 & 53 & M & 90 & $\varnothing$ & + & $\varnothing$ & 34 & 120 & $\varnothing$ & 100 \\
\hline 9 & 61 & M & 100 & $\varnothing$ & + & 34.860 & 126 & 50 & 239 & 176 \\
\hline 10 & 44 & M & 35 & $\varnothing$ & + & 6.73 & 113 & 55 & 57 & 210 \\
\hline $11^{*}$ & 38 & M & 90 & $\varnothing$ & + & 9.62 & 82 & 40 & 101 & 128 \\
\hline 12 & 57 & M & 20 & $\varnothing$ & + & 28,000 & 120 & 90 & 610 & 310 \\
\hline 13 & 76 & M & 30 & $\varnothing$ & - & 1.65 & 54 & 69 & 19 & 127 \\
\hline $14^{*}$ & 50 & $\mathrm{~F}$ & 40 & $\varnothing$ & $\varnothing$ & $\varnothing$ & $\varnothing$ & $\varnothing$ & $\varnothing$ & $\varnothing$ \\
\hline $15^{*}$ & 48 & $M$ & 25 & $\varnothing$ & + & 3828 & 53 & 66 & 27 & 101 \\
\hline 16 & 70 & M & 30 & + & $\varnothing$ & $\varnothing$ & 46 & 21 & 21 & 131 \\
\hline $17^{*}$ & 68 & $\mathrm{~F}$ & 25 & + & $\varnothing$ & 28.7 & 89 & 70 & 100 & 129 \\
\hline $18^{*}$ & 70 & M & 25 & $\varnothing$ & + & 355 & 23 & 21 & 28 & 195 \\
\hline 19 & 55 & $\mathrm{~F}$ & 20 & + & $\varnothing$ & 155 & 149 & 179 & 98 & 264 \\
\hline 20 & 51 & $\mathrm{~F}$ & 17 & $\varnothing$ & + & 513 & 67 & 30 & 80 & 161 \\
\hline $21 *$ & 54 & $\mathrm{~F}$ & 26 & $\varnothing$ & + & 800 & 89 & 49 & 169 & 121 \\
\hline 22 & 56 & $M$ & 100 & $\varnothing$ & $\varnothing$ & $\varnothing$ & 90 & 1000 & $\varnothing$ & 85 \\
\hline $23^{*}$ & 53 & $\mathrm{~F}$ & 50 & $\varnothing$ & $\varnothing$ & 1.54 & 42 & 32 & 92 & 142 \\
\hline $24 *$ & 28 & M & 24 & $\varnothing$ & + & 532.5 & 46 & 128 & 29 & 159 \\
\hline 25 & 51 & M & 30 & $\varnothing$ & + & 7.2 & 49 & 38 & 148 & 170 \\
\hline 26 & 65 & $M$ & 25 & $\varnothing$ & + & $\varnothing$ & 130 & 210 & 22 & 81 \\
\hline 27 & 51 & M & 20 & $\varnothing$ & + & 47.3 & 75 & 39 & 46 & 97 \\
\hline $28^{*}$ & 48 & M & 25 & $\varnothing$ & + & 4 & 40 & 55 & 48 & 110 \\
\hline 29 & 55 & $\mathrm{~F}$ & 30 & $\varnothing$ & + & 9.2 & 60 & 30 & 90 & 87 \\
\hline $30^{*}$ & 60 & $\mathrm{~F}$ & 40 & $\varnothing$ & + & 27 & 75 & 65 & 60 & 150 \\
\hline
\end{tabular}

*Positive staining in malignant hepatocytes for hepatocyte growth factor; $\varnothing$ Unknown; + Positive. AFP Alpha-fetoprotein; ALT Alanine aminotransferase; AP Alkaline phosphatase; AST Aspartate aminotransferase; GGT Gamma glutamyl transferase; HBsAg Hepatitis B surface antigen; HCV Hepatitis C virus

Statistical analysis: The Wilcoxon test and the $t$ test were used to analyze the statistical relationships among the groups. $\mathrm{P}<0.05$ was considered significant.

\section{RESULTS}

Immunohistochemical staining revealed diffusely scattered HGF-positive cells in all groups. While the staining was limited to nonparenchymal cells (Kupffer, Ito and sinusoidal endothelial cells) in groups I and II (Figure 1), in group III (HCC) the hepatocytes also stained (Figure 2 top, bottom). It was only possible to assess nonmalignant hepatocytes adjacent to the HCC in the four resection specimens, and these cases showed no positive staining for HGF in this area. The density of nonmalignant nonparenchymal positive cells in all groups was significantly higher than that in the control specimens. Also, the density of these cells in group I was significantly higher than that in groups II $(\mathrm{P}<0.05)$ and III $(\mathrm{P}<0.05)$ (Table 2$)$. No association between the density of HGF-positive cells and grade of
TABLE 2

Causes of liver diseases in the study groups

\begin{tabular}{lcccccc}
\hline & HCV & HBV & $\begin{array}{c}\text { Alcohol } \\
\text { abuse }\end{array}$ & $\begin{array}{c}\text { Cryptogenic } \\
\text { cirrhosis }\end{array}$ & $\begin{array}{c}\text { Neonatal } \\
\text { hepatitis }\end{array}$ & $\begin{array}{c}\text { Autoimmune } \\
\text { disease }\end{array}$ \\
\hline HCC & 6 & 22 & 2 & - & - & - \\
$\mathrm{CH}$ & 13 & 5 & 1 & - & - & 1 \\
$\mathrm{C}$ & 5 & 9 & 3 & 2 & 1 & - \\
\hline \multicolumn{7}{l}{ C Cirrhosis; CH Chronic hepatitis; HBV Hepatitis B virus; HCC Hepa- }
\end{tabular}
tocellular carcinoma; HCV Hepatitis C virus

HCC ( $>0.05)$ (Table 3), or between the density of HGFpositive cells and HAI in $\mathrm{CH}$ specimens $(\mathrm{P}>0.05)$ was found (Table 4).

There was cytoplasmic HGF positivity in the hepatocytes of 10 cases (33.3\%) from group III. The distribution of HCC grading in these 10 patients was as follows: no grade I cases, two grade II cases, five grade III cases and three grade 


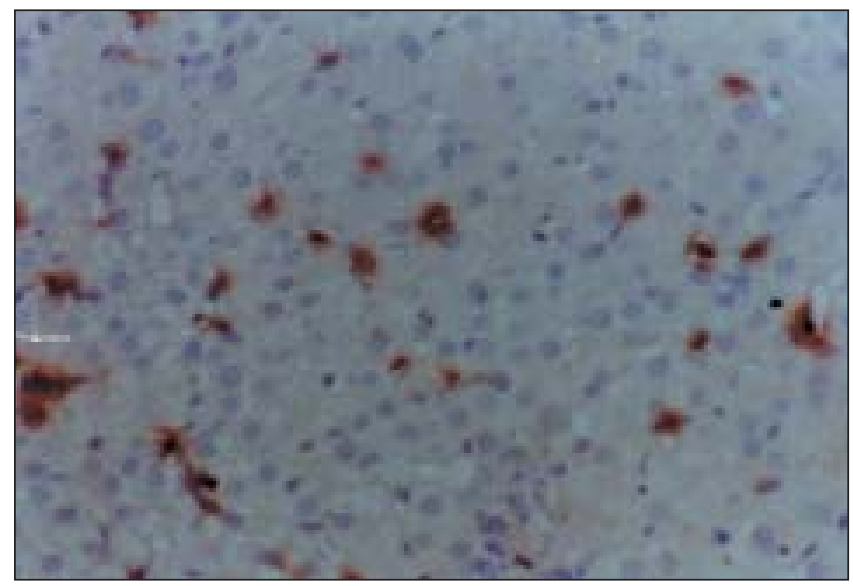

Figure 1) Hepatocyte growth factor staining in the Kupffer and Ito cells of specimens from groups I and II (Immunoperoxidase, original magnification $\times 115$ )
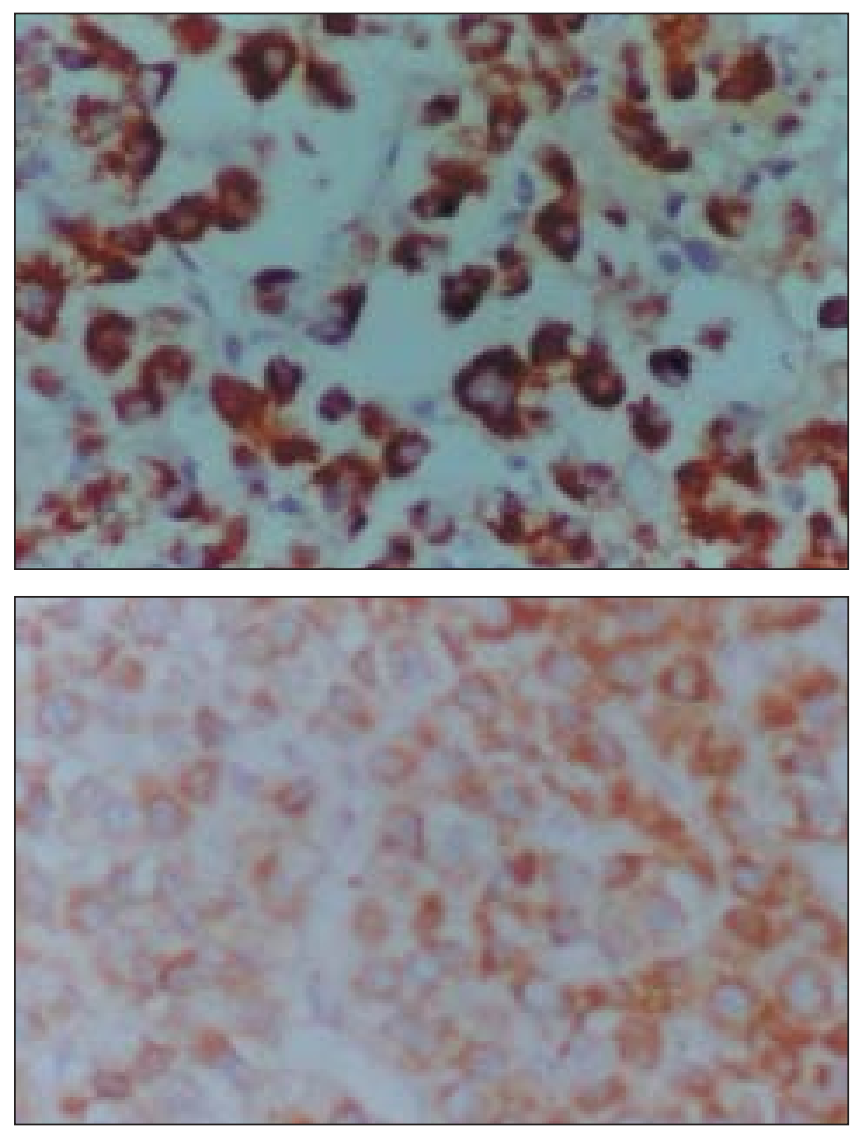

Figure 2) Top In group III (hepatocellular carcinoma), malignant hepatocytes showed cytoplasmic staining for hepatocyte growth factor (immunoperoxidase, original magnification $\times 460$ ). Bottom Cytoplasmic staining for hepatocyte growth factor in hepatoma cells (immunoperoxidase, original magnification $\times 230$ )

IV cases (Table 5). Marked cytoplasmic staining was observed in the hepatocytes of four cirrhosis and four $\mathrm{CH}$ specimens, but this was identified as iron deposition (Figure 3 top, bottom). In contrast, no iron deposition was found in the 10 specimens from group III that had HGF-positive hepatoma cells (Figure 4 top, bottom). In addition, a diffuse
TABLE 3

Comparison of hepatocyte growth factor (HGF)-positive nonparenchymal cell density in groups I, II and III

\begin{tabular}{lcc}
\hline Group & Number of cases & $\begin{array}{c}\text { HGF-positive cells } / \mathbf{m m}^{\mathbf{2}} \\
\text { (mean } \pm \text { SD) }\end{array}$ \\
\hline Chronic hepatitis* & 20 & $27 \pm 9.90$ \\
Cirrhosis & 20 & $18.10 \pm 10.03$ \\
$\begin{array}{l}\text { Hepatocellular } \\
\text { carcinoma }\end{array}$ & 30 & $13.03 \pm 7.90$ \\
Control & 20 & $2.95 \pm 1.43$ \\
\hline
\end{tabular}

*Count in group I was significantly higher than the count in the other groups (t test; $P<0.05$ )

\section{TABLE 4}

Relationship between hepatocyte growth factor (HGF)-positive nonparenchymal cell density and grade in hepatocellular carcinoma (HCC)

\begin{tabular}{|c|c|c|}
\hline Grade of HCC* & Number of cases & $\begin{array}{l}\text { Density of staining for HGF } \\
\text { antibody (HGF-positive } \\
\text { cells } / \mathbf{m m}^{2}, \text { mean } \pm \text { SD) }\end{array}$ \\
\hline I & 3 & $16.27 \pm 7.17$ \\
\hline II & 12 & $9.79 \pm 6.44$ \\
\hline III & 12 & $14.04 \pm 8.83$ \\
\hline IV & 3 & $18.62 \pm 8.11$ \\
\hline
\end{tabular}

*There was no association between the density of HGF-positive nonparenchymal cells and grade of HCC (Wilcoxon test, $P>0.05$ )

TABLE 5

Relationship between histological activity index (HAI) and hepatocyte growth factor (HGF)-positive nonparenchymal cell density in patients with chronic hepatitis

\begin{tabular}{lcc}
\hline HAI* & Number of cases & $\begin{array}{c}\text { Density of staining for HGF } \\
\text { antibody (HGF-positive } \\
\text { cells/mm }{ }^{2} \text {, mean } \pm \text { SD) }\end{array}$ \\
\hline Very low & 10 & $21.91 \pm 7.42$ \\
Low & 8 & $33.07 \pm 11.61$ \\
Medium & - & - \\
High & 2 & $25.10 \pm 7.21$ \\
\hline
\end{tabular}

*There was no association between the density of HGF-positive nonparenchymal cells and HAI (Wilcoxon test; $P>0.05$ )

pattern of oval-shaped noncytoplasmic globules that stained positive for HGF was noted in two of the cirrhosis specimens. These two cases exhibited severe cholestasis on $H \& E$ staining (Figure 5 top, bottom). Two patients in the cirrhosis group showed cholestasis as well, but the degree of cholestasis was minimal, and there was no staining for HGF in these two patients.

\section{DISCUSSION}

HGF is known to be a multipotent growth factor. Previous work has shown that the expression of HGF is associated with tissue regeneration, wound healing, normal tissue growth, tumour progression, embryogenesis and tumour invasion $(13,17,18)$. The level of expression is increased in some patients with chronic active hepatitis (19). 

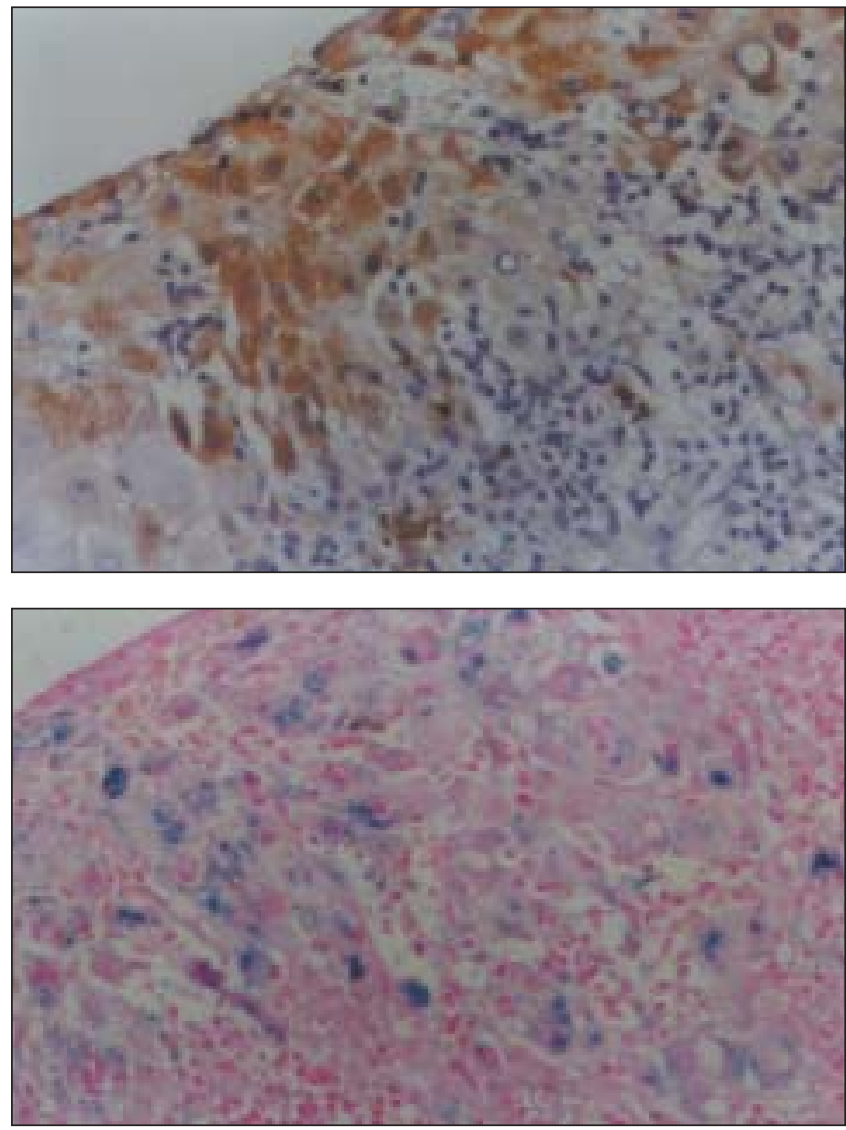

Figure 3) Top Marked cytoplasmic staining for hepatocyte growth factor in the nonmalignant hepatocytes of a chronic hepatitis specimen (immunoperoxidase, original magnification $\times 115$ ). Bottom The staining reflects iron deposition (Perls' iron, original magnification $\times 115$ )

Investigation has proved that serum HGF levels are linked to HAI in this group $(10,19)$. Our findings concurred with some of these earlier results in that immunohistochemical staining for $\mathrm{HGF}$ was of significantly higher density in $\mathrm{CH}$ specimens than in those from cirrhosis and HCC patients $(\mathrm{P}<0.05$ and $\mathrm{P}<0.05$, respectively); however, we found no association between density of HGF-positive cells and HAI $(\mathrm{P}>0.05)$. This could be a reflection of the small number of $\mathrm{CH}$ patients studied. These findings are in line with previous results indicating that hepatocyte growth factor is produced and expressed by nonparenchymal cells in nonneoplastic liver disease.

Peptide growth factors are thought to be involved in the pathogenesis of hepatic fibrosis, and overexpression of transforming growth factor beta-1 (TGF- $\beta 1$ ) has been proposed as an important initial step. Although HGF is expressed in $\mathrm{CH}$, elevated TGF- $\beta 1$ levels suppress HGF expression and induce hepatic fibrosis (20). All but one of the $\mathrm{CH}$ cases exhibited minimal fibrosis; thus, we contend that TGF- $\beta 1$ levels were low and did not suppress HGF in these patients.

A particularly interesting aspect of this study was the detection of HGF in HCC cells. As noted earlier, HGF is
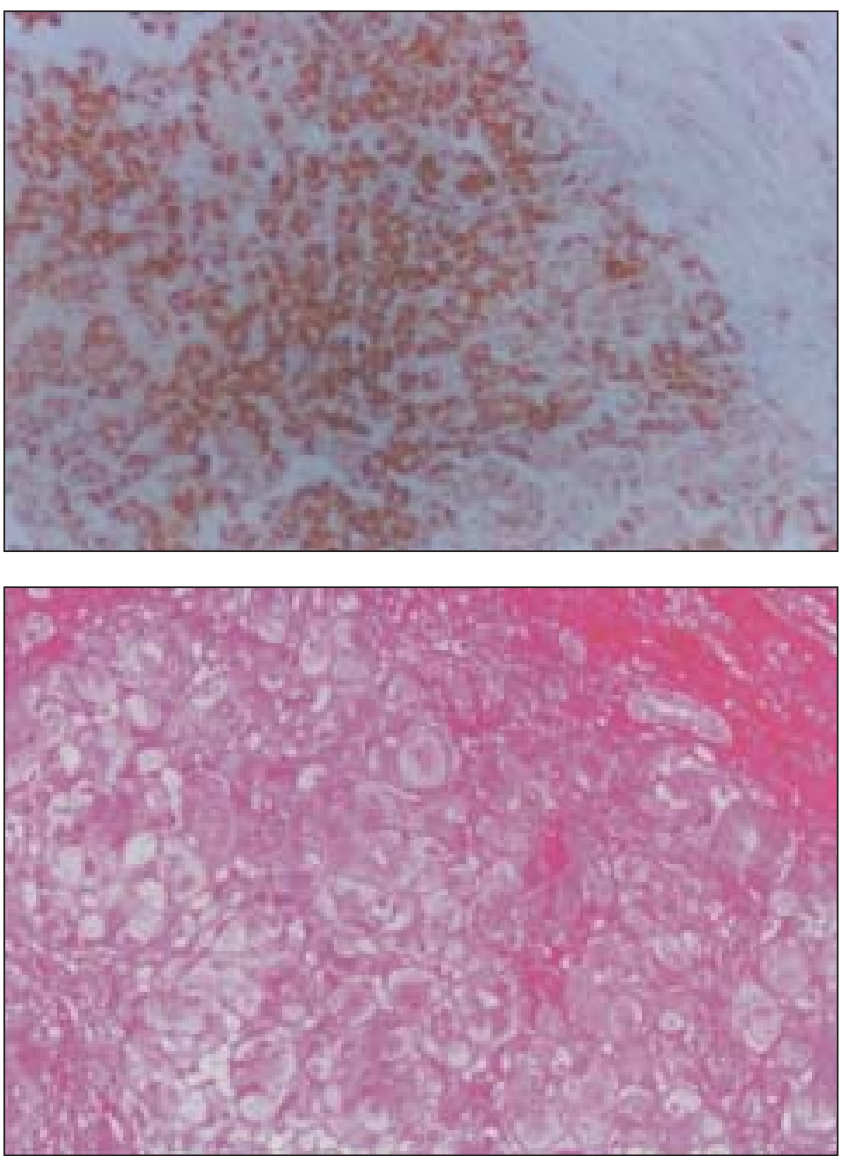

Figure 4) Top Cytoplasmic staining for hepatocyte growth factor in malignant hepatocytes in a case of hepatocellular carcinoma (immunoperoxidase, original magnification $\times 46$ ). Bottom No iron deposition is seen (Perls' iron, original magnification $\times 230$ )

known to be expressed in nonparenchymal cells, such as Kupffer, Ito and endothelial cells, both in normal tissue and in various liver diseases $(11,19,21-23)$. Most articles on this subject have stated that HGF may be detected in nonparenchymal cells within HCC nodules, but that neoplastic hepatocytes do not produce this factor $(11,19,21,24-26)$. In contrast, other reports have shown that some hepatoma cells do stain with HGF $(13,27)$. One of these was an experimental study in rats, but the other was an investigation of human liver tissue. The latter authors reported that five of their six HCC cases had hepatoma cells that stained HGFpositive, and concluded that these cells were expressing HGF (13). Similarly, previous reports have documented HGF production by some carcinoma cells (lung carcinoma and glioblastoma cells). In our investigation, hepatoma cells in 10 of the $30 \mathrm{HCC}$ cases stained positive for HGF. To confirm the specificity of our result, we ruled out the presence of pigments known to cross-react with HGF, including iron, lipofucsin and bile.

Concerning other possible confounding findings, careful analysis of the four cirrhosis and four $\mathrm{CH}$ specimens that showed marked cytoplasmic staining for HGF in the hepatocytes revealed that this staining was due to iron deposi- 

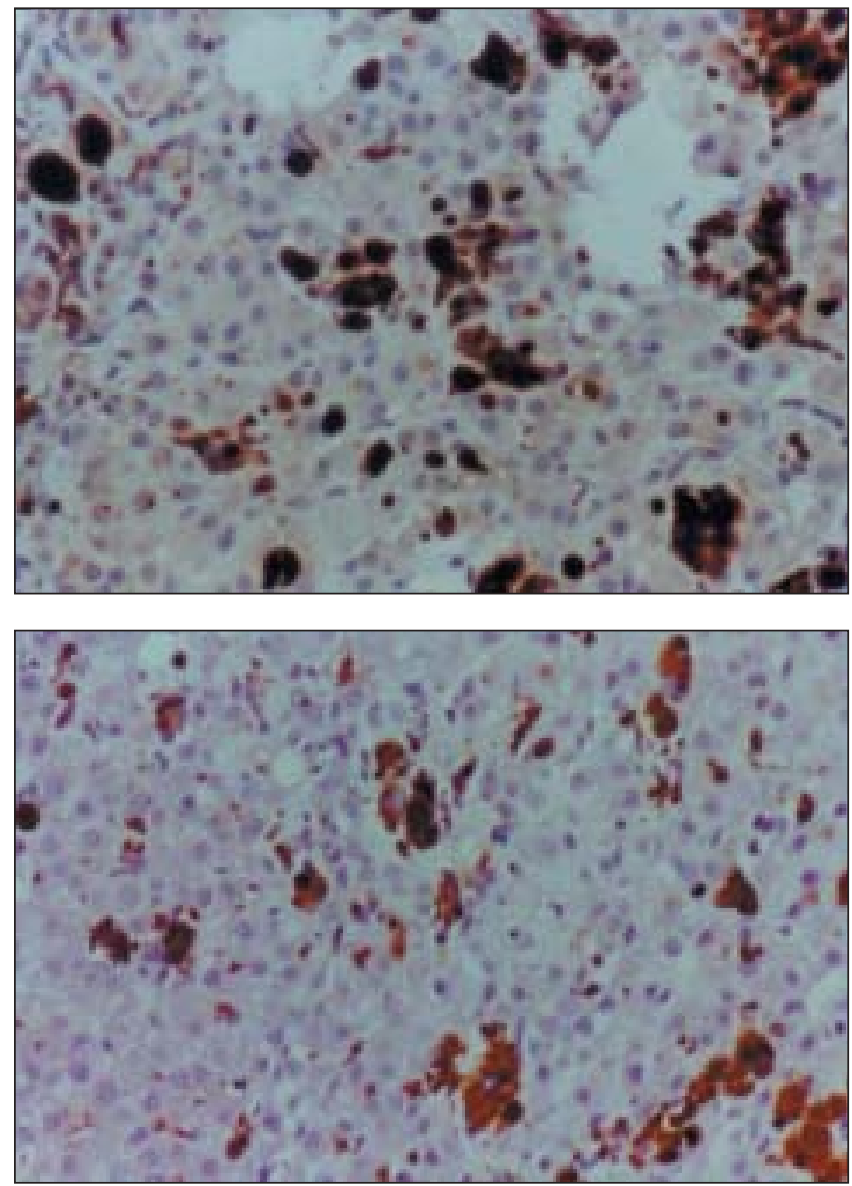

Figure 5) Top A diffuse pattern of oval-shaped noncytoplasmic globules showed marked staining for hepatocyte growth factor (immunoperoxidase, original magnification $\times 115)$. Bottom Severe cholestasis was exhibited (hematoxylin and eosin stain, original magnification $\times 115$ )

tion. In addition, we noted a diffuse pattern of oval-shaped noncytoplasmic globules that stained positive for HGF in two of the cirrhosis specimens. These two cases exhibited severe cholestasis on $H \& E$ staining, whereas this was not observed in the other slides. We concluded that, before hepatocyte staining with HGF can be confirmed as a valid finding, hemosiderosis and cholestasis must be ruled out.

\section{REFERENCES}

1. Uchiyama H, Yanaga K, Nishizaki T, Soejima Y, Yoshizumi T, Sugimachi K. Effects of deletion variant of hepatocyte growth factor on reduced-size liver transplantation in rats. Transplantation 1999;68:39-44.

2. Liu ML, Mars WM, Michalopoulos GK. Hepatocyte growth factor inhibits cell proliferation in vivo of rat hepatocellular carcinomas induced by diethylnitrosamine. Carcinogenesis 1995; 16:841-3.

3. Mizuno K, Higuchi O, Tajima H, Yonemasu T, Nakamura T. Cell density-dependent regulation of hepatocyte growth factor receptor on adult rat hepatocytes in primary culture. J Biochem (Tokyo) 1993;114:96-102

4. Jiang WG, Hallett MB, Puntis MC. Hepatocyte growth factor/ scatter factor, liver regeneration and cancer metastasis. Br J Surg 1993;80:1368-73.

5. Michalopoulos GK, Appasamy R. Metabolism of HGF-SF and its role in liver regeneration. EXS 1993;65:275-83.
TABLE 6

Density of hepatocyte growth factor (HGF)-positive cells in hepatoma cells according to grade of disease

\begin{tabular}{lc}
$\begin{array}{l}\text { Grade of } \\
\text { hepatocellular carcinoma }\end{array}$ & HGF-positive hepatocytes $/ \mathbf{m m}^{\mathbf{2}}$ \\
\hline I $(n=0)$ & - \\
II $(n=2)$ & $20,7.6$ \\
III $(n=5)$ & $10,11.4,13.7,21.8,5.75$ \\
IV $(n=3)$ & $23.3,23.3,9.25$ \\
\hline
\end{tabular}

On this basis, we examined the immunohistochemically stained and H\&E-stained specimens simultaneously. Regarding a possible link between HGF positivity and treatment received at the time of biopsy, none of the patients in the HCC and cirrhosis groups were undergoing specific therapy, and only three patients in the $\mathrm{CH}$ group were receiving interferon. On this basis, we believe that the HGF expression that we observed was likely not influenced by any therapy.

Concerning potential relationships between HCC grade and HGF positivity, we observed that none of the $10 \mathrm{HGF}$ positive HCC cases exhibited grade I differentiation. However, our analysis revealed no association between density of HGF-positive cells and grade of HCC (Table 6). We think that there may be a connection between the reasons why hepatoma cells in grade I disease do not stain for HGF and why normal and non-neoplastic liver tissues do not stain.

In summary, our results should be considered preliminary. While they concur with the findings of some previous reports, other studies have failed to detect HGF in malignant cells. Our results may be related to the antibody that we applied. To our knowledge, our laboratory is the first to have used this antibody. If further research proves that hepatoma cells do produce this growth factor, immunohistochemical staining for HGF may be a valuable method for diagnosing well differentiated HCC. More investigation is required to determine the possible mechanisms of HGF staining in HCC.

6. Tsubouchi H. Hepatocyte growth factor for liver disease. Hepatology 1999;30:333-4.

7. Ikegami T, Nishizaki T, Uchiyama H, Hashimoto K, Yanaga K, Sugimachi K. Experimental study of the effects of deletion variant of hepatocyte growth factor on hepatic ischaemia-reperfusion injury. Br J Surg 2000;87:59-64.

8. Gohda E, Nakamura S, Yamamoto I, Minowada J. Hepatocyte growth factor-pleiotropic cytokine produced by human leukemia cells. Leuk Lymphoma 1995;19:197-205.

9. Noji S, Tashiro K, Koyama E, et al. Expression of hepatocyte growth factor gene in endothelial and Kupffer cells of damaged rat livers, as revealed by in situ hybridization. Biochem Biophys Res Commun 1990;173:42-7.

10 Shiota G, Okano JI, Kawasaki H, Kawamoto T, Nakamura T. Serum hepatocyte growth factor levels in liver diseases: Clinical implications. Hepatology 1995;21:106-12.

11. Ueki T, Fujimoto J, Suzuki T, Yamamoto H, Okamoto E. Expression 
of hepatocyte growth factor and its receptor, the c-met protooncogene, in hepatocellular carcinoma. Hepatology 1997;25:619-23.

12. Selden C, Farnaud S, Ding SF, Habib N, Foster C, Hodgson HJF. Expression of hepatocyte growth factor mRNA, and c-met mRNA (hepatocyte growth factor receptor) in human liver tumours. J Hepatol 1994;21:227-34.

13. Ljubimova JY, Petroviç LM, Wilson SE, Geller SA, Demetriou AA. Expression of HGF, its receptor c-met, c-myc, and albumin in cirrhotic and neoplastic human liver tissue. J Histochem Cytochem 1997; 45:79-87.

14. Edmondson HA, Steiner PE. Primary carcinoma of the liver. A study of 100 cases among 48,900 necropsies. Cancer 1954;7:462-503.

15. Knodell RG, Ishak KG, Black WC, et al. Formation and application of a numerical scoring system for assessing histological activity in asymptomatic chronic active hepatitis. Hepatology 1981;1:431-5.

16. Prophet EB, Mills B, Arrington JB, Sobin LH. Laboratory Methods in Histotechnology, 1st edn. Washington: American Registry of Pathology, 1992.

17. Miyazawa K, Shimomura T, Kitamura N. Activation of hepatocyte growth factor in the injured tissues is mediated by hepatocyte growth factor activator. J Biol Chem 1996;271:3615-8.

18. Yoshinaga Y, Matsuno Y, Fujita S, et al. Immunohistochemical detection of hepatocyte growth factor/scatter factor in human cancerous and inflammatory lesions of various organs. Jpn J Cancer $1993 ; 84: 1150-8$.
19. Noguchi O, Enomoto N, Ikeda T, Kobayashi F, Marumo F, Sato C. Gene expressions of c-met and hepatocyte growth factor in chronic liver disease and hepatocellular carcinoma. J Hepatol 1996;24:286-92.

20. Wrana JL. Transforming growth factor $-\beta$ signaling and cirrhosis. Hepatology 1999;29:1909-10.

21. Hung Ho RT, Liew CT, Lai KN. The expression of hepatocyte growth factor (HGF) and interleukin 6 (IL-6) in damaged human liver and kidney tissues. Hepatogastroenterology 1999;46:1904-9.

22. Motoki Y, Tamura H, Morita R, Watanabe T, Suga T. Decreased hepatocyte growth factor level by $\mathrm{Wy}-14,643$, non-genotoxic hepatocarcinogen in F-344 rats. Carcinogenesis 1997;18:1303-9.

23. Matsumoto K, Nakamura T. Hepatocyte growth factor: molecular structure and implications for a central role in liver regeneration. J Gastroenterol Hepatol 1991;6:509-19.

24. Hu RH, Lee PH, Yu SC, Sheu JC, Lai MY. Serum hepatocyte growth factor before and after resection for hepatocellular carcinoma. Hepatogastroenterology 1999;46:1842-7.

25. Matsumoto K, Nakamura T. Hepatocyte growth factor: molecular structure, roles in liver regeneration, and other biological functions. Crit Rev Oncog 1992;3:27-54.

26. Matsuda Y, Nakamura T. Molecular biology of hepatocyte growth factor. Nippon Rinsho 1993;51:435-45.

27. Nakayama N, Kashiwazaki H, Kobayashi N, et al. Hepatocyte growth factor and c-met expression in Long-Evans cinnamon rats with spontaneous hepatitis and hepatoma. Hepatology 1996;24:596-602. 


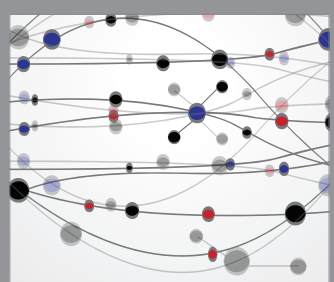

The Scientific World Journal
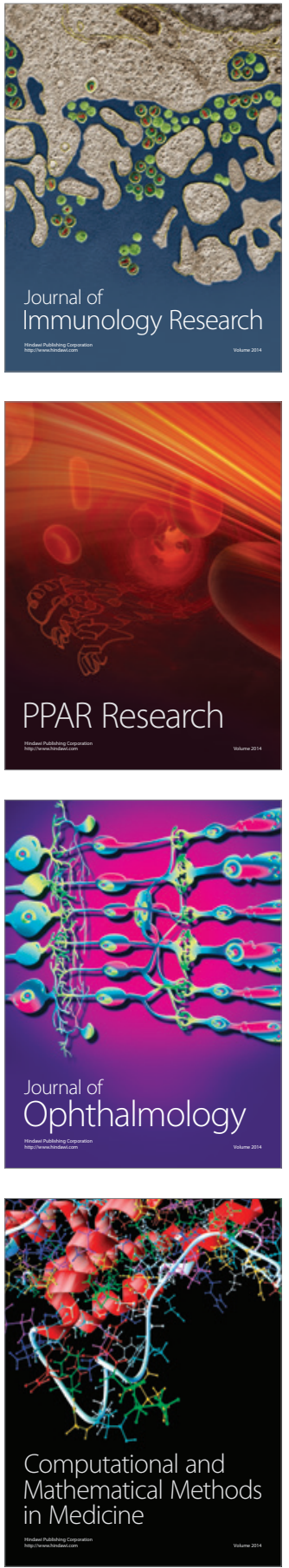

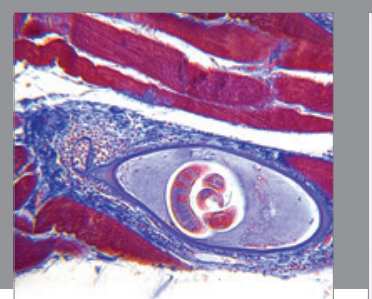

Gastroenterology Research and Practice

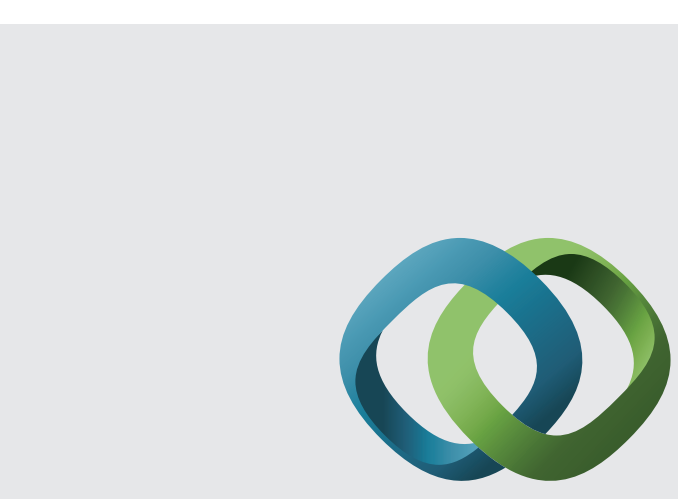

\section{Hindawi}

Submit your manuscripts at

http://www.hindawi.com
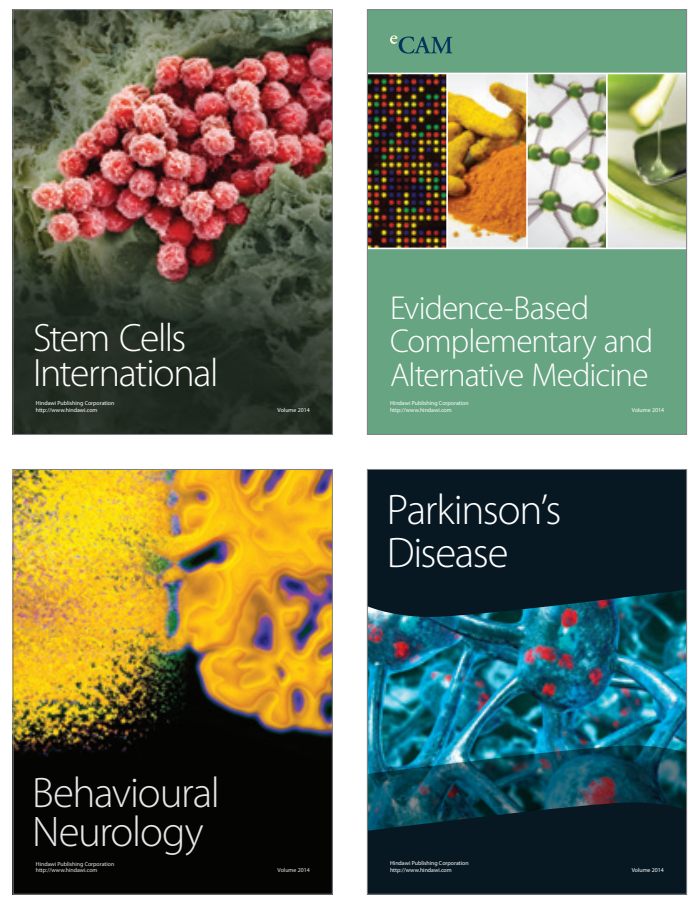
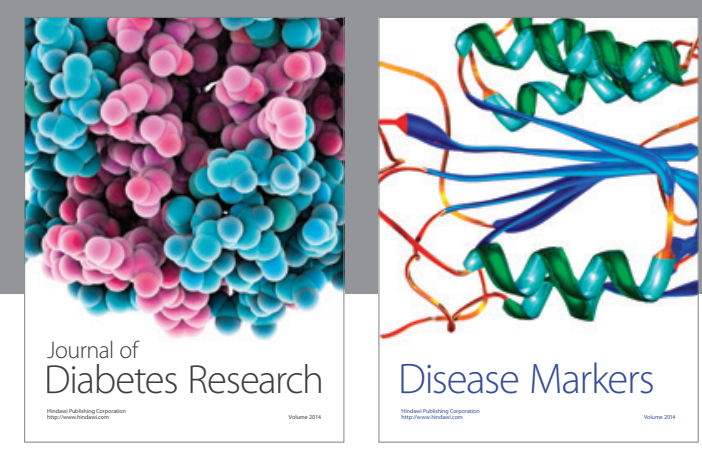

Disease Markers
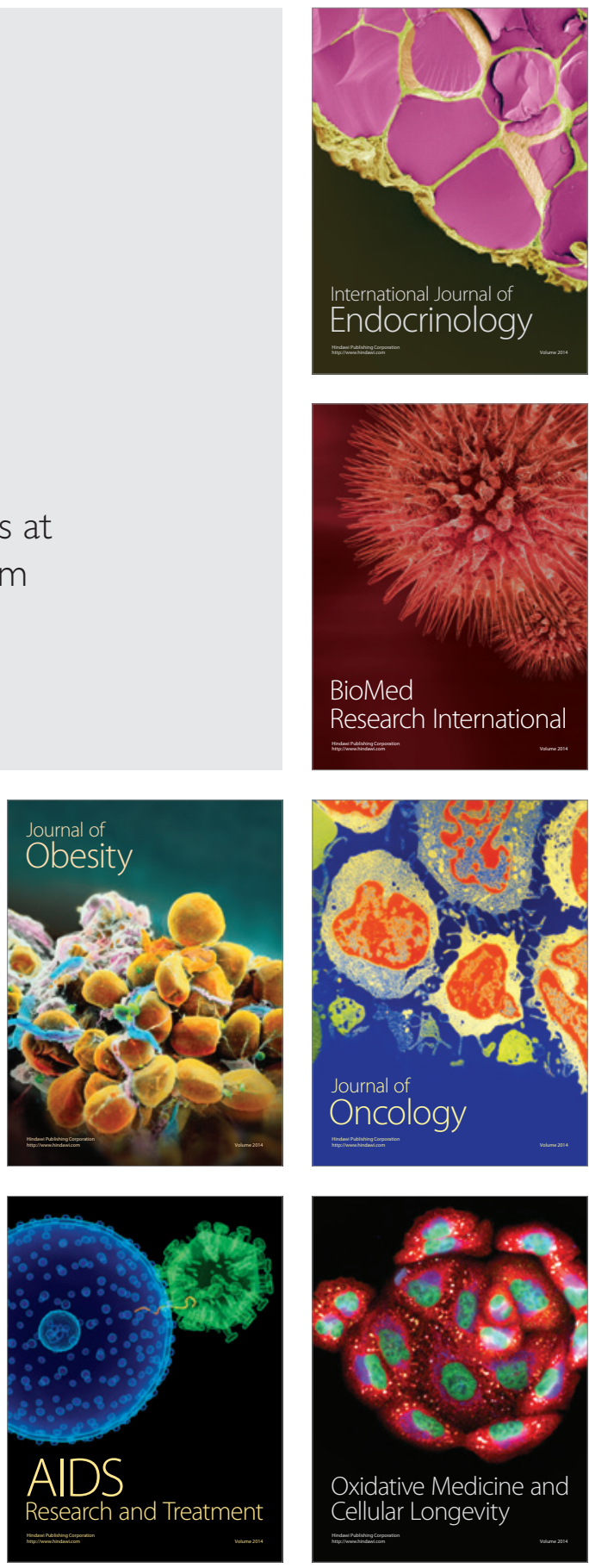